\title{
PENINGKATAN PENGETAHUAN PETERNAK SAPI DI DESA ALEBO KECAMATAN KONDA MELALUI BIMBINGAN TEKNIS CARA BETERNAK YANG BAIK
}

\author{
Harapin Hafid ${ }^{1}$, Nuraini ${ }^{2}$, La Ode Ba'a ${ }^{3}$, La Malesi ${ }^{4}$, Siti Hadrayanti Ananda ${ }^{5}$, Peni Patriani ${ }^{6}$ \\ ${ }^{1,2,3,4}$ Fakultas Peternakan Universitas Halu Oleo, Kendari \\ ${ }^{5}$ Studi Program Ilmu Gizi, STIKES Karya Kesehatan, Kendari \\ ${ }^{6}$ Fakultas Peternakan, Universitas Sumatera Utara, Medan \\ email harapin.hafid@uho.ac.id
}

\begin{abstract}
ABSTRAK
Sulawesi Tenggara termasuk daerah sumber ternak sapi di Indonesia. Secara umum peternakan sapi masih dikelola secara tradisional oleh masyarakat, sehingga terdapat banyak problematika dalam pengembangannya. Kegiatan pengabdian masyarakat ini berjudul peningkatan pengetahuan peternak sapi di desa Alebo kecamatan Konda melalui bimbingan teknis cara beternak yang baik. Mitra Program Kemitraan Masyarakat adalah Kelompok Peternak Sapi Sumber Rejeki di Desa Alebo Kecamatan Konda Kabupaten Konawe Selatan Provinsi Sulawesi Tenggara yang diketuai oleh bapak Jasruddin dan sekretaris bapak Sampun. Permasalahan yang dialami peternak adalah masih rendahnya produktivitas berupa rendahnya pertumbuhan ternak (rendahnya pertambahan bobot badan harian), rendahnya nafsu makan ternak, kualitas pakan yang rendah dan banyak kejadian ternak cacingan dan gejala sakit lainnya. Solusi dari permasalahan di atas dapat diatasi dengan memberikan bimbingan teknis cara beternak yang baik berupa pemberian pengetahuan kepada peternak sapi di Kelompok Peternak Sumber Rejeki Di Alebo Desa Kecamatan Konda. Luaran yang dapat diperoleh dari kegiatan ini adalah adanya peningkatan pengetahuan peternak tentang cara beternak yang baik. Metode yang digunakan adalah penyuluhan dan bimbingan teknis pendampingan cara beternak sapi potong yang baik. Hasil kegiatan pengabdian kepada masyarakat berupa bimbingan teknis yang terkait dengan upaya mengatasi permasalahan yang selama ini terjadi pada peternak sapi di desa Alebo, khususnya pada Kelompok Ternak Sumber Rejeki. Materi yang dipaparkan pada bimbingan teknis berupa pemilihan bibit ternak yang baik, manajemen reproduksi dan sistem perkawinan, sistem perkandangan, manajemen pemeliharaan ternak, dan hijauan pakan ternak dan teknologi pengolahan pakan serta kesehatan dan pengendalian penyakit mendapat sambutan dan respon yang sangat baik dan antusias dari peserta, ditandai dengan banyaknya pertanyaan dan permintaan peserta agar desa Alebo dijadikan desa binaan agar selalu mendapat bimbingan teknis teknologi peternakan yang berkesinambungan. Disimpulkan bahwa peternak sapi di desa Alebo masih banyak mengalami kendala dalam usaha peternakannya yang bersifat tradisional. Kendala utama adalah gangguan reproduksi, investasi cacing, rendahnya kualitas, kuantitas dan kontinuitas pakan, manajemen pemeliharaan yang masih tradisional, perkandangan dan sanitasi yang perlu diperbaiki. Disarankan agar peternak sapi di desa Alebo dibina secara berkala oleh LPPM Universitas Halu Oleo sehingga bisa menjadi kawasan peternakan sapi yang maju dan modern.
\end{abstract}

Kata Kunci: ternak sapi, bimbingan teknis, cara beternak yang baik. 


\begin{abstract}
Southeast Sulawesi is a source of cattle in Indonesia. In general, cattle farming is still managed traditionally by the community, so there are many problems in its development. This community service activity is titled increasing the knowledge of cattle farmers in Alebo village, Konda sub-district through technical guidance on how to raise good animals. Partners of the Community Partnership Program are Sumber Rejeki Cattle Breeders Group in Alebo Village, Konda Subdistrict, South Konawe Regency, Southeast Sulawesi Province, chaired by Mr. Jasruddin and Secretary of Mr. Sampun. The problems experienced by breeders are still low productivity in the form of low livestock growth (low daily body weight gain), low appetite of livestock, low quality of feed and many incidences of intestinal worms and other symptoms of illness. The solution to the above problems can be overcome by providing technical guidance on how to raise livestock in the form of providing knowledge to cattle farmers in the Rejeki Sumber Farmer Group in Alebo Village, Konda District. The output that can be obtained from this activity is an increase in farmers' knowledge about good farming practices. The method used is counseling and technical guidance for how to raise good beef cattle. The results of community service activities in the form of technical guidance related to efforts to overcome the problems that have been happening to cattle ranchers in Alebo village, especially in Sumber Rejeki Livestock Group. The material presented in the technical guidance in the form of good livestock breeding, reproduction management and mating systems, housing systems, livestock raising management, and animal feed and feed processing technology as well as health and disease control received very good and enthusiastic responses and responses from the participants, marked by the many questions and requests of participants so that the village of Alebo was made a target village so that they would always receive technical guidance on sustainable animal husbandry technology. It was concluded that cattle ranchers in Alebo village still experienced many obstacles in their traditional farming business. The main constraints are reproductive disorders, worm investment, poor quality, quantity and continuity of feed, traditional maintenance management, housing and sanitation that need to be improved. It is recommended that cattle breeders in Alebo village be periodically fostered by LPPM Halu Oleo University so that they can become an advanced and modern cattle ranch area.
\end{abstract}

Keywords: cattle, technical guidance, good farming methods.

\title{
PENDAHULUAN
}

\section{Analisis Situasi}

Bagaimanapun bagus bibit dan pakan ternak membutuhkan pengelolaan peternakan yang baik. Pengelolaan peternakan yang didasarkan pada cara berproduksi yang baik dapat meningkatkan produksi peternakan (Hafid, 2008). Desa Alebo merupakan daerah eks transmigrasi yang berasal dari Jawa, Jawa Barat, Bali dan Sulawesi Selatan serta berbaur penduduk lokal seperti suku Tolaki, Muna dan Buton. Menurut data Kecamatan Konda sampai dengan awal 2015, terdapat jumlah kepala keluarga sekitar $275 \mathrm{KK}$, dimana sebagian besar penduduk di desa tersebut bermata pencaharian sebagai petani. Usaha tani yang dilakukan adalah padi ladang, tanaman hortikultura, sayur-sayuran, tanaman palawija seperti jagung, kacang-kacangan serta perkebunan kakao, nilam, lada dan fanili. 
Selain mata pencaharian utama tersebut, usaha sampingan yang dominan dilakukan masyarakat adalah memelihara ternak terutama ternak sapi. Aktivitas pemeliharaan sapi di daerah ini merupakan bagian yang tidak terpisahkan dari usaha tani yang dilakukan masyarakat, karena semak hasil penyiangan tanaman dan limbah tanaman merupakan bahan pakan serta pupuk kandang yang dihasilkan dari pemeliharaan sapi dimanfaatkan dan sangat dibutuhkan untuk meningkatkan kesuburan tanah dan hasil tanaman mereka. Namun di sisi lain limbah tanaman pangan dan perkebunan yang dihasilkan belum dimanfaatkan secara optimal sebagai pakan ternak sapi seperti pengolahan silase, urea molasses blok, hay dan lainnya. Pada umumnya peternak hanya memanfaatkan pakan hijauan berupa rumput dan legum yang tersedia di lahan pertanian mereka.

Pengembangan usaha ternak sapi di desa Alebo sangat potensial, karena selain didukung oleh ketersediaan pakan alami dan pakan yang berasal dari hasil sampingan tanaman pangan dan perkebunan, juga didukung oleh budaya beternak yang cukup baik dari masyarakat eks transmigran. Disamping itu, sebagian besar petani-ternak berada pada usia produktif sehingga secara fisik peternak memiliki kemampuan untuk mengurus ternaknya. Sapi yang dipelihara adalah sapi potong jenis sapi Bali dengan sistem pemeliharaan yang masih tradisional dan semi intensif yang dipelihara dengan ditambatkan di pekarangan atau dikandang secara kelompok maupun individu. Menurut catatan PPL Peternakan Kecamatan Konda, yang salah satu wilayah kerjanya di desa Alebo sampai saat ini jumlah populasi sapi di Desa Alebo sekitar 450 ekor yang merupakan hasil pertambahan alamiah dari populasi sebelumnya. Adanya peningkatan populasi tersebut menunjukkan bahwa peternak di daerah ini memiliki perhatian dan harapan yang cukup besar untuk menjadikan usaha ternak sapi sebagai salah satu sumber pendapatan keluarga. Akan tetapi secara umum, sistem pengelolaan usaha ternak sapi yang dilakukan petani-ternak masih sangat terbatas, baik dari produksi maupun manajemen. Oleh karenanya perlu mendapat perhatian dari pihak-pihak terkait terutama dalam bentuk upgrading pengetahuan dan keterampilan melalui kegiatan bimbingan teknis dan aplikasi teknologi peternakan yang relevan.

Berdasarkan hasil wawancara dengan kelompok ternak Sumber Rezeki di Desa Alebo diketahui bahwa para petani-ternak daerah ini membutuhkan bimbingan teknis dan pendampingan untuk mengembangkan potensi usaha yang mereka miliki. Serta adanya penyuluhan-penyuluhan dari pihak akademisi atau pihak pemerintah untuk membantu memberikan solusi terhadap kondisi peternakan di daerah ini. 
Potensi ternak sapi di kecamatan Konda kabupaten Konawe Selatan sangat berpeluang besar untuk dikembangkan karena tingginya animo masyarakat. Potensi ini juga didukung oleh potensi sumberdaya lokal berupa bibit sapi yang sudah ada dan memadai serta potensi pakan dari limbah pertanian-perkebunan yang diusahakan bisa dimanfaatkan secara maksimal. Disisi lain ternak sapi berkontribusi sebagai sumber pendapatan, investasi dan tabungan, dibutuhkan untuk keperluan ritual agama misalnya untuk qurban pada saat Idul Adha dan pelengkap adat pada ritual pernikahan, denda adat, dan sebagainya. Pengembangan sistem usaha dari semi intensif ke tradisional di kecamatan Konda kabupaten Konawe Selatan dapat memberikan motivasi bagi masyarakat di sekitarnya untuk memadukan usaha pertanian mereka dengan ternak sapi dimana dapat disinergikan limbah hasil pertanian sebagai pakan ternak dan kotoran sapi atau pupuk kandang sebagai pupuk tanaman. Potensi lain yang mendukung tingginya permintaan sapi sebagai hewan potongan untuk memenuhi kebutuhan konsumsi daging pada masyarakat di Kota Kendari dan sekitarnya.

Melalui program PKM ini diharapkan usaha ternak sapi yang dilakukan petani-ternak di Desa Alebo Kecamatan Konda Kabupaten Konawe Selatan mendapat sentuhan ilmu pengetahuan dan teknologi sehingga semakin bertumbuh subur pada masa yang akan datang.

\section{Permasalahan Mitra}

Setelah beberapa kali melakukan kunjungan (survey) dan berdiskusi dengan pihak mitra yaitu kelompok ternak Sumber Rezeki di Desa Alebo Kecamatan Konda Kabupaten Konawe Selatan, terdapat beberapa permasalahan yang disepakati dan menjadi prioritas untuk ditangani adalah sebagai berikut:

1) Pertumbuhan anak sapi rendah dan bobot badan dewasa cenderung mengalami penurunan dari tahun ke tahun, ditandai dengan rendahnya pertambahan bobot badan harian ternak. Hal ini diduga disebabkan oleh rendahnya kualitas bibit dan intensifnya perkawinan inbreeding yang berlangsung dari generasi ke generasi. Selain itu, faktor pakan induk bunting dan menyusui yang tidak atau kurang memenuhi kebutuhan induk juga berpengaruh terhadap rendahnya bobot lahir dan produksi susu, terganggunya pertumbuhan anak sapi serta rendahnya pencapaian bobot dewasa (Blakely dan Bade, 1994; Tillman, et al., 1989; Hafid, et al., 2011; Hafid, et al., 2018; Hafid, et al., 2019).

2) Rendahnya kualitas pakan sangat berpengaruh terhadap performa produksi sapi, apatah lagi apabila jumlah pakan yang diberikan tidak mencukupi kuantitasnya serta tidak berkesinambungan (Hartadi, 1991; Tillman, et al., 1989). Rendahnya pertumbuhan sapi pada kedua desa mitra akan ditingkatkan 
dengan memperbaiki kualitas pakan dan pengolahan limbah pertanian menjadi bahan pakan bernilai gizi tinggi.

3) Angka mortalitas (kematian) anak sapi pra-sapih sering terjadi sehingga memperlambat laju peningkatan populasi. Hal ini diduga akibat rendahnya produksi susu induk dan terbatasnya kemampuan peternak dalam penanganan anak dan induk setelah partus (kelahiran). Disamping itu angka kelahiran (calf crop) juga rendah yang mungkin disebabkan karena rendahnya kualitas (fertilitas) induk dan pejantan yang ada (Blakely dan Bade, 1994).

4) Ternak sapi sering terserang parasit cacing dan kembung (bloat). Hal ini diduga terjadi karena kurangnya sanitasi kandang, peralatan makan-minum dan lingkungan sekitar kandang terutama di paddock-paddock pengembalaan atau kebun rumput potongan. Kebiasaan peternak melepas cepat ternak pada pagi hari serta minum air yang kotor dapat menjadi penyebab investasi cacing dan kembung, demikian pula pemberian legume segar tanpa dilayukan juga menjadi penyebab terjadinya kembung. Penyakit kembung dan cacing menyebabkan terganggunya pertumbuhan ternak sapi (Akoso, 1996).

5) Pengetahuan dan keterampilan peternak tentang manajemen dan produksi, terutama pemberian pakan relatif rendah. Umumnya peternak hanya memperhatikan kuantitas pakan yang diberikan tanpa memperhitungkan kualitas gizi berdasarkan kebutuhan dan atau umur sapi, pada umumnya pakan yang diberikan hanya rumput alam dan semak/legum yang diarit disekitar kebun, pematang dan saluran air. Di sisi lain limbah pertanian seperti jerami yang banyak tersedia belum dimanfaatkan sebagai pakan melalui tindakan pengolahan (Darmono.1993; Suharno dan Nazaruddin, 1994).

6) Perkandangan dan sanitasi belum memadai, terutama tingginya kelembaban dalam kandang disebabkan menumpuknya kotoran dan lantai kandang mudah becek oleh urine karena masih merupakan lantai tanah dengan drainase yang kurang memadai (Sugeng, 2000; Siregar, S. B. 2002).

7) Pengetahuan tentang pengolahan kotoran ternak menjadi pupuk kandang yang berkualitas perlu ditingkatkan dengan pengolahan lebih lanjut menggunakan teknologi pengomposan (Abidin, 2002; Arianto dan Sarwono, 2002).

Selain permasalahan teknis yang telah diuraikan di atas, pengetahuan peternak mengenai teknik pemeliharaan intensif, kemampuan manajemen usaha dan pengelolaan kelompok ternak masih perlu ditingkatkan. Akumulasi berbagai permasalahan di atas menyebabkan tingkat produktivitas dan 
reproduktivitas ternak sapi di Desa Alebo menjadi rendah. Padahal jika dikelola dengan baik, seekor induk sapi dapat melahirkan setiap tahun sehingga peternak akan mendapatkan tambahan anak sapi setiap tahun. Jika peternak dapat memanfaatkan potensi ini maka sangat memungkinkan meningkatnya pendapatan dan kesejahteraan mereka.

\section{Solusi Yang Ditawarkan}

Berdasarkan uraian permasalahan di atas, maka solusi yang ditawarkan untuk menangani permasalahan yang dihadapi kelompok peternak sapi di Desa Alebo dan Morome adalah sebagai berikut:

1. Perbaikan tatalaksana pemeliharaan, meliputi:

- Perbaikan kandang dan peralatan sesuai fungsinya.

- Pemeliharaan dan perawatan induk bunting, induk menyusui, remaja dan pejantan.

- Penanganan kelahiran dan penanganan anak dan induk setelah kelahiran.

2) Perbaikan kualitas pakan, dimana pakan yang diberikan kepada sapi disesuaikan dengan kebutuhan fase produksi dengan mengoptimalkan pemanfaatan bahan baku pakan yang berasal dari limbah pertanian.

3) Peningkatan pengetahuan petani peternak tentang pemilihan bibit yang baik dan mencegah terjadinya inbreeding yang intensif.

4) Peningkatan pengetahuan petani peternak tentang pengembangbiakan ternak khususnya pengetahuan tentang ciri ternak berahi, intensifikasi kawin alam dan inseminasi buatan dengan menggunakan semen pejantan unggul.

5) Peningkatan pengetahuan petani peternak tentang hijauan makanan ternak unggul dan teknologi pakan yang memanfaatkan limbah hasil pertanian, seperti pembuatan silase, hay maupun urea molasses blok.

6) Peningkatan pengetahuan petani peternak tentang kesehatan hewan terutama terhadap penanganan ternak sapi yang terinvestasi cacing dan penyakit kembung (bloat) dan cara pengobatannya.

\section{Target Luaran}

Target luaran dari kegiatan ini berupa: (1) metode beternak sapi potong yang lebih baik yang berpedoman kepada teknologi peternakan modern, (2) produk berupa sapi-sapi yang sehat dan gemuk serta mampu berkembang biak dengan baik, dan (3) Artikel ilmiah. 
Dengan kegiatan PKM ini maka diharapkan terjadi proses transformasi teknologi di masyarakat khususnya mitra kelompok ternak Sumber Rezeki di Desa Alebo Kecamatan Konda Kabupaten Konawe Selatan, mulai beralih dari metode beternak secara tradisional menjadi beternak secara modern sehingga produktivitas usaha peternakan menjadi lebih baik karena sapi bisa berkembang biak dengan cepat dan efisien, sehat dan bertumbuh dengan baik sehingga diperoleh sapi yang gemuk dan diperoleh harga jual yang lebih tinggi serta hasil dari penjualan/pemanfaatan pupuk kandang, yang berarti meningkatkan pendapatan kelompok peternakan sapi potong.

\section{METODE}

Pelaksanaan program PKM pada mitra kelompok ternak Sumber Rezeki di Desa Alebo Kecamatan Konda Kabupaten Konawe Selatan.

\section{Metode Pendekatan}

Pelaksanaan pelatihan akan menggunakan dua metode pendekatan yaitu :

1) Ceramah dan diskusi: Pendekatan ini dilakukan untuk memberi pemahaman teoritis kepada peserta pelatihan, tentang teknis intensifikasi pemeliharaan ternak sapi, perbaikan produktivitas, manajemen usaha dan pengelolaan kelompok yang kuat.

2) Demonstrasi dan praktek lapang. Pendekatan ini bertujuan untuk memperkenalkan paket teknologi intensifikasi pemeliharaan ternak sapi secara langsung kepada kelompok peternak, mulai pemilihan bibit, pengenalan tanda-tanda birahi dan sistem perkawinan alam, pengenalan hijauan makanan ternak, teknologi pengolahan pakan, penyusunan dan pemberian pakan, pengendalian penyakit dan sanitasi.

3) Pendampingan. Pendekatan ini dilakukan untuk memberikan bimbingan teknis dan penyuluhan bagi seluruh anggota kelompok peternak dalam praktek dan manajemen peternakan.

\section{Bahan dan Alat}

Bahan dan alat yang digunakan pada kegiatan pelatihan meliputi: makalah pelatihan, seminarkit pelatihan, infocus multimedia, digital camera, note book, komputer, printer dan lain-lain). Bahan dan alat yang digunakan dalam kegiatan demontrasi lapang (demplot) antara lain, pengenalan bahan pakan, kandang dan peralatannya, peralatan IB, dan sampel ternak sapi serta vaksin dan obat-abatan. 


\section{Materi Pelatihan}

Materi pelatihan yang akan diberikan adalah sebagai berikut:

1) Teknologi pembibitan ternak

2) Manajemen reproduksi dan sistem perkawinan

3) Sistem perkandangan

4) Manajemen pemeliharaan dan perawatan

5) Teknologi pengolahan pakan

6) Kesehatan dan pengendalian penyakit

\section{Langkah-Langkah Pelaksanaan Program}

Pelaksanaan program PKM ini akan dilakukan dengan langkah-langkah sebagai berikut:

1) Sosialisasi Program

Sosialisasi program kegiatan selain dilakukan kepada pengurus dan anggota kelompok peternak ternak sapi, juga melibatkan stakeholdes terkait seperti Kepala Desa, Ketua Badan Pemberdayaan Desa, Dewan Perwakilan Desa, tokoh agama dan tokoh masyarakat. Hal ini bertujuan untuk menyamakan persepsi dan menggalang dukungan dari stakeholders demi suksesnya program PKM yang akan dilaksanakan. Dalam kegiatan sosialisasi ini sekaligus membahas dan menetapkan rencana pelaksanaan program kegiatan.

2) Pelaksanaan Program Kegiatan

- Pelatihan

- Pendampingan

3) Monitoring dan Evaluasi Program

Monitoring dan evaluasi program dilakukan secara internal oleh LPPM Universitas Halu Oleo. Monev internal dilakukan dengan tujuan untuk mengikuti perkembangan dan keberlanjutan kegiatan serta mengeliminir faktor penghambat dan mengoptimalkan faktor pendukung pelaksanaan program.

4) Pelaporan

Laporan pelaksanaan program PKM ini akan disampaikan pada akhir pelaksanaan kegiatan. 


\section{PEMBAHASAN}

Pada awal kegiatan, tim pelaksana pengabdian melakukan persiapan awal dengan cara survey ke kelompok ternak untuk mengidentifikasi permasalahan-permasalahan terkait usaha peternakan sapi potong, kemudian dilanjutkan dengan diskusi dan menyepakati jadwal pelaksanaan kegiatan pengabdian dengan mitra Kelompok Peternak Sapi Sumber Rezeki, agar pelaksanaan pengabdian ini dapat berjalan dengan lancar sehingga dapat mengatasi permasalahan yang ada. Dalam konsultasi jadwal pelaksanaan turut dikonfirmasi kesediaan bapak Kepala Desa Alebo, serta diminta kesediaan untuk menghadiri dan mengarahkan acara.

Pada tahap pengadaan bahan bimbingan teknis, tim pelaksana pengabdian menyusun bahan bimbingan teknis yang terkait dengan permasalahan-permasalahan di bidang:

1) Pemilihan bibit ternak yang baik

2) Manajemen reproduksi dan sistem perkawinan

3) Sistem perkandangan

4) Manajemen pemeliharaan ternak

5) Hijauan Pakan Ternak dan Teknologi pengolahan pakan

6) Kesehatan dan pengendalian penyakit

Pada tahap bimbingan teknis cara beternak yang baik dilakukan bimbingan teknis dengan ceramah penyuluhan yang bertempat di balai pertemuan desa Alebo diikuti oleh anggota Kelompok Peternak Sapi Sumber Rezeki.

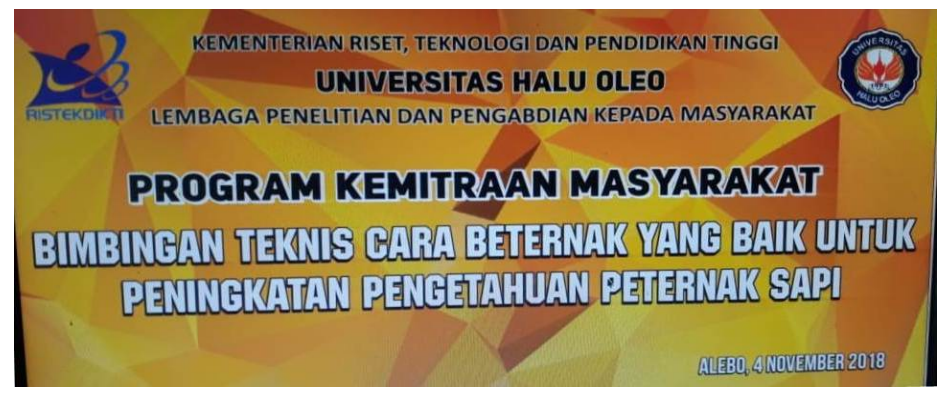

Gambar 1. Spanduk Bimbingan Teknis

Pada saat pembukaan bimbingan teknis bapak kepala desa Alebo (Abdul Manaf Zani), beliau meminta para peserta mengikuti dengan seksama dan aktif dalam menyampaikan permasalahan terkait peternakan sapi yang telah lama dilaksanakan oleh masyarakat (anggota kelompok ternak), beliau juga menyampaikan selamat datang dan meminta kepada tim pelaksana pengabdian untuk memberikan ilmu 
dan teknologi peternakan yang paling cocok dan sesuai dengan kondisi peternak di desa Alebo. Disamping itu Kepala Desa juga meminta kesediaan tim pelaksana dari Fakultas Peternakan Universitas Halu Oleo untuk sering-sering berkunjung ke desa Alebo untuk membantu memotivasi dan mencari solusi atas permasalahan yang dihadapi para peternak, misalnya dengan menjadikan kawasan desa Alebo sebagai wilayah binaan peternakan sapi.

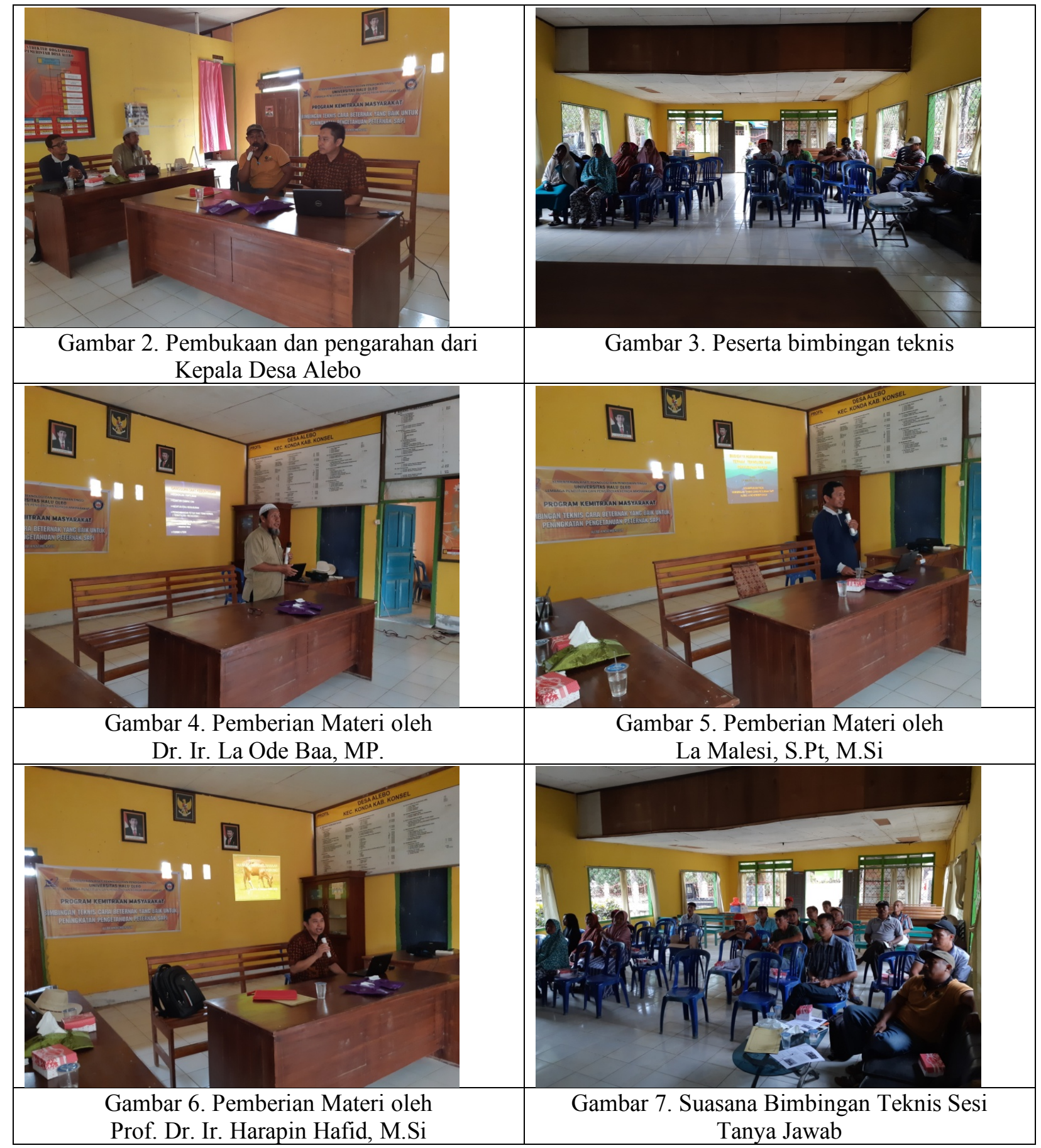


Sesi Pertama, pemateri Dr. Ir. La Ode Baa, MP. menyampaikan materi tentang manajemen reproduksi dan sistem perkawinan kesehatan dan pengendalian penyakit. Pada sesi ini banyak mendapat pertanyaan peternak terkait cara mendeteksi sapi yang birahi karena banyak kejadian sapi tidak pernah bunting karena tidak jelas masa birahinya (estrus), ada juga yang mempertanyakan terkait ganguan reproduksi yaitu kesulitan melahirkan dimana plasenta sulit keluar saat proses kelahiran (retensio plasenta) dan tertahannya plasenta diluar tubuh setelah melahirkan (prolaposus uteri) pada sapi seperti terlihat pada Gambar 8 dan 9 berikut.

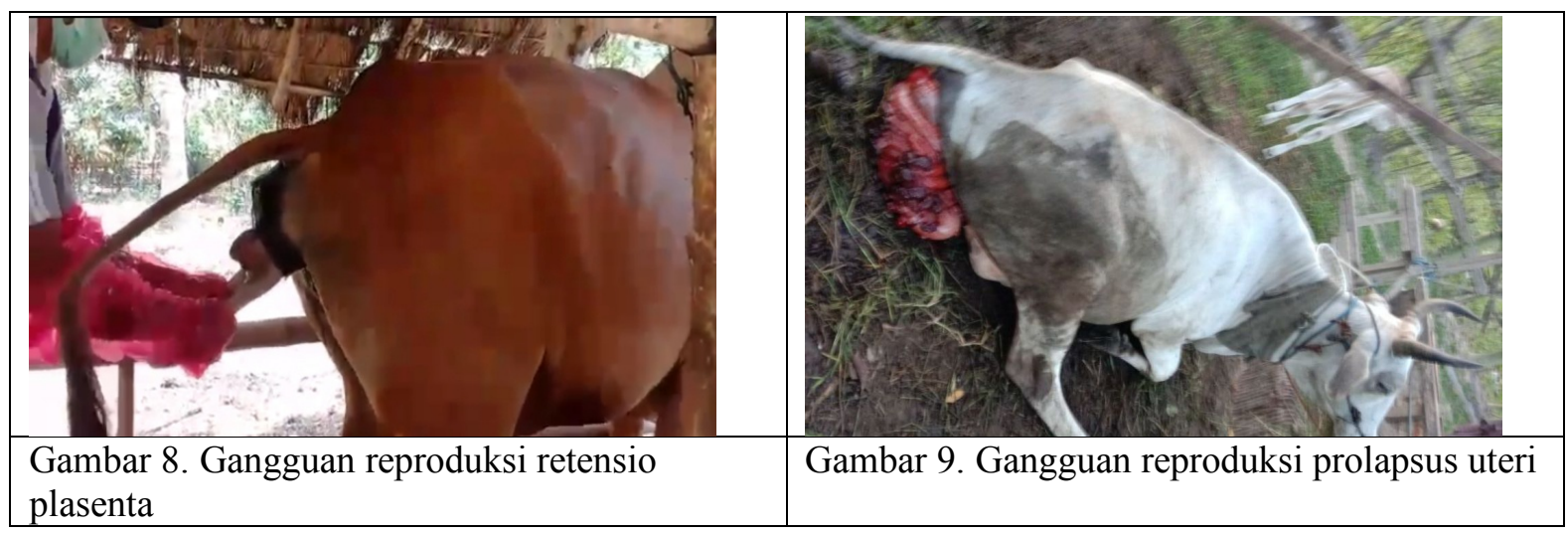

Pertanyaan dijawab oleh pemateri dengan memperlihatkan beberapa slide terkait proses awal reproduksi ternak terutama terkait masalah birahi dan problem solusinya, demikian slide tentang proses kelahiran normal dan cara penanganan gangguan reproduksi. Pada kesempatan ini pemeteri menyarankan perlunya exercise atau alokasi waktu bagi sapi untuk berjalan di luar kandang menjelang masa kelahiran sehingga terjadi proses relaksasi yang normal pada otot-otot yang berhubungan dengan proses kelahiran.

Pada sesi kedua pemateri La Malesi, S.Pt., M.Si membawakan materi tentang Hijauan Pakan Ternak dan Teknologi pengolahan pakan. Terkait hijauan pakan ternak dijelaskan berbagai macam jenis hijau pakan ternak baik hijauan potongan (rumput dan leguminosa) maupun gembalaan serta hijauan sisa hasil pertanian berupa jerami padi, jerami jagung, jerami kedelai dan sisa hasil pembuatan tahu berupa ampas tahu yang bergizi untuk ternak sapi. Juga dijelaskan cara membuat silase, hay dan urea molasses blok. Pada sesi ini peserta mempertanyakan terkait sulitnya mendapatkan pakan di musim kemarau serta bagaimana cara mengolah jerami padi atau jagung agar disukai ternak sapi dan agar bisa meningkat nilai gizinya. Pertanyaan ini dijawab oleh pemateri dengan memperlihatkan slide terkait permasalahan yang ditanyakan sebagai berikut (Gambar 10 dan 11). 


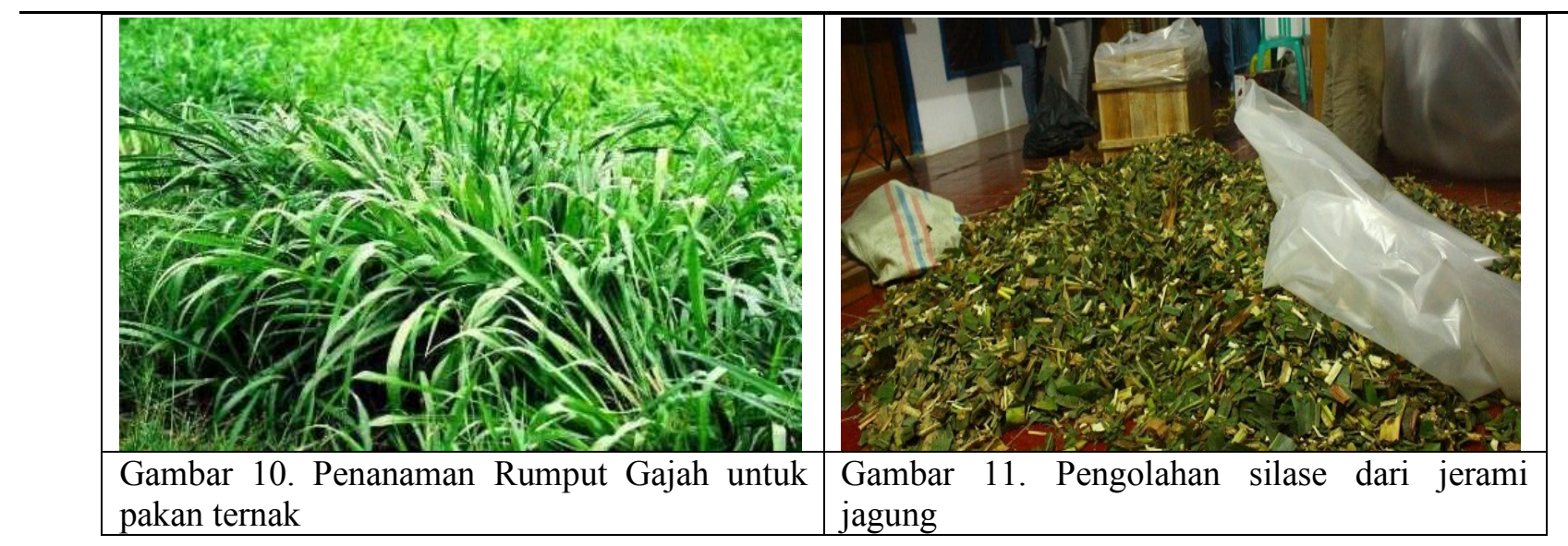

Pada sesi ketiga, materi terkait sistem perkandangan, bibit ternak yang baik dan manajemen pemeliharaan dipaparkan oleh Prof. Dr. Ir. Harapin Hafid, M.Si. Terkait sistem perkandangan diuraikan tujuan pengandangan ternak, manfaat yang diperoleh, bahan kandang yang kuat tapi murah, konstruksi kandang dan sanitasi (biosekuriti). Terkait materi bibit ternak yang baik dipaparkan tentang asal usul ternak, daya adaptasi, tipe ternak dan ciri-ciri bibit ternak sapi potong khususnya sapi Bali yang baik. Dan pada materi manajemen pemeliharaan diuraikan tentang cara-cara penanganan ternak sapi potong yang terkait tatalaksana/manajemen pemeliharaan masa pedet (anak atau calf), pemeliharaan masa remaja (dara/heifer dan remaja jantan/bullock) dan pemeliharaan sapi dewasa (induk/cow dan bull/pejantan). Pada sesi ini banyak pertanyaan peserta yang terkait dengan bagaimana konstruksi kandang yang baik dan sehat, serta bagaimana mana karakteristik pejantan yang baik yang bisa menghasilkan keturunan yang baik pula berupa anak yang sehat dan berpostur besar. Pertanyaan dijawab oleh pemateri dengan memperlihatkan dan menjelaskan slide yang terkait seperti terlihat pada Gambar 12 dan 13 berikut.

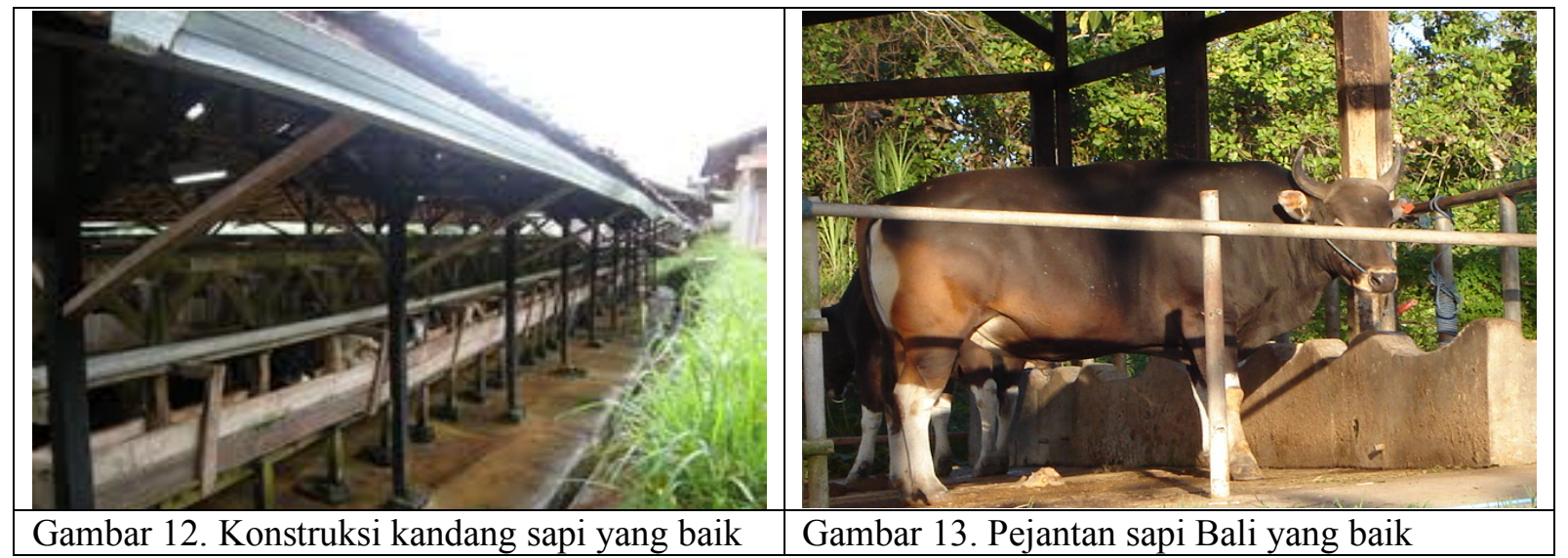


Pendampingan dilaksanakan dengan melakukan pemantauan berkala terhadap kondisi peternakan sapi di desa Alebo. Kegiatan ini bekerjasama dengan penyuluh lapangan (PPL) bapak Sampun yang juga merupakan sekretaris kelompok ternak sapi Sumber Rezeki. Demikian pula dengan kerjasama bapak ketua kelompok peternak bapak Jasmadi serta anggota kelompok yang akan secara proaktif menyampaikan lewat telepon, pesan singkat (sms maupun whatshap) jika terdapat permasalahan di lapangan.

\section{SIMPULAN}

Secara keseluruhan pengabdian ini telah berhasil dengan baik. Mitra sangat antusias dalam menyambut kegiatan bimbingan teknis. Adanya upaya dari mitra sendiri untuk melanjutkan ke tahap berikutnya untuk menjadikan usaha peternakan sapi di desa Alebo semakin berkembang dan menjadi sentra sumber bibit sapi di Provinsi Sulawesi Tenggara. Kegiatan pengabdian kepada masyarakat ini dapat menjadi upaya pemberdayaan masyarakat yang lebih luas dalam rangka penciptaan peluang usaha dan tambahan lapangan kerja bagi masyarakat khususnya di pedesaan, yang sekaligus bisa menciptakan lingkungan hidup bersih lestari.

Sebaiknya dilakukan kegiatan pendampingan lebih lanjut oleh tim pelaksana di desa Alebo dan desa sekitarnya dengan difasilitasi oleh Lembaga Penelitian dan Pengabdian Universitas Halu Oleo sehingga pengembangan ternak potong bisa lebih cepat dan terarah.

\section{UCAPAN TERIMAKASIH}

Ucapan terima kasih disampaikan kepada Rektor Universitas Halu Oleo dan Ketua Lembaga Penelitian dan Pengabdian Kepada Masyarakat yang telah mendanai kegiatan ini melalui dana DIPA Universitas Halu Oleo Tahun Anggaran 2018 dengan Surat Perjanjian Pelaksanaan Pekerjaan Nomor : 3887/UN29.2.1/KU/2018.

\section{DAFTAR PUSTAKA}

Akoso, B. T. 1996. Kesehatan Sapi. Kanisius, Yogyakarta.

Abidin, Z. 2002. Penggemukan Sapi Potong. Agro Media Pustaka, Jakarta. 
Arianto, H. B., B. Sarwono. 2002. Penggemukan Sapi Potong Secara Cepat. Cetakan I. Penebar Swadaya, Jakarta.

Blakely, J., D.H. Bade. 1994. Ilmu Peternakan. Gadjah Mada University Press, Yogyakarta. (Diterjemahkan B. Srigandono).

Darmono.1993. Tatalaksana Sapi Kereman. Kanisius, Yogyakarta.

Hafid, H. 2011. Pengantar Evaluasi Karkas. Cetakan Pertama. Unhalu Press, Kendari.

Hafid H. 2008. Strategi Pengembangan Peternakan Sapi Potong Di Sulawesi Tenggara Dalam Mendukung Pencapaian Swasembada Daging Nasional. Orasi Ilmiah Pengukuhan Guru Besar. Universitas Haluoleo, Kendari.

Hafid. H. R. E. Gurnadi. R. Priyanto., A. Saefuddin. 2010. Identification of carcass characteristic for estimating the compotion of beef carcass. J. Indonesian Trop. Anim. Agric. 35 (1): 22-26.

Hafid. H. Nuraini. Inderawati dan W. Kurniawan. 2018. Beef cattle characteristic of different butt shape condition. IOP Conf. Series Earth and Environmental Science. Page 1-6.

Hafid. H., Hasnudi. H.A. Bain. F. Nasiu., Inderawati. P. Patriani., S.H. Ananda. 2019. Effect of fasting time before slaughtering on body weight loss and carcass percentage of bali cattle. IOP Conf. Series Earth and Environmental Science. Page 1-7.

Hartadi, H. S., S. Reksohadiprodjo., A. D. Tillman. 1991. Tabel Komposisi Pakan untuk Indonesia. Gadjah Mada University Press, Yogyakarta.

Murtidjo, B. A. 2002. Beternak Sapi Potong. Kanisius, Yogyakarta.

Suharno, B. dan Nazaruddin. 1994. Ternak Komersial. Penebar Swadaya, Jakarta.

Ratnawati, D., W.C. Pratiwi., L. Affandhy. 2007. Petunjuk Teknis Penanganan Gangguan Reproduksi Pada Sapi Potong. Penerbit Loka Penelitian Sapi Potong, Grati.

Sugeng, Y. B. 2000. Sapi Potong. Penebar Swadaya, Jakarta.

Siregar, S. B. 2002. Penggemukan Sapi. Cetakan ke 6. Penerbit Swadaya, Jakarta.

Tillman, A. D., H. Hartadi, S. Reksohadiprodjo, S. Prawirokusumo., S. Lebdo Soekotjo. 1989. Ilmu Makanan Ternak Dasar. Gadjah Mada University Press, Yogyakarta. 